\title{
Factors Associated with Nasal Intermittent Positive Pressure Ventilation Failure in Late Preterm and Term Infants with Respiratory Distress after Birth
}

\author{
Gyu Hong Shim, MD, PhD
}

Department of Pediatrics, Inje University Sanggye Paik Hospital, Seoul, Korea

\section{ABSTRACT}

Purpose: We examined the factors associated with nasal intermittent positive pressure ventilation (NIPPV) failure in late preterm and term infants with respiratory distress after birth.

Methods: A retrospective cohort study was conducted on late preterm and term infants with respiratory distress after birth from January 2015 to December 2020. The medical records of 132 infants, who received NIPPV as primary respiratory therapy before 6 hours of age, were retrospectively examined. We excluded five neonates who were either transferred to another hospital ( $\mathrm{n}=2)$ or presented with congenital anomalies $(\mathrm{n}=3)$.

Results: The remaining 127 neonates were divided into the NIPPV success group $(n=82)$ and NIPPV failure group $(n=45)$. NIPPV failure was associated with birth in a community hospital, the need for a surfactant, and a high maximum respiratory severity score (RSS $\geq 2.5$ ) on the first day of life. In the subgroup analysis, NIPPV failure in late preterm infants was associated with a lower gestational age, birth in a community hospital, and an RSS $\geq 2.5$ on the first day of life. In addition, NIPPV failure in term infants was associated with birth in a community hospital, the need for a surfactant, and an RSS $\geq 2.5$ on the first day of life.

Conclusion: Birth in a community hospital, the need for a surfactant, and an RSS $\geq 2.5$ on the first day of life were significant factors associated with NIPPV failure in late preterm and term infants.

Key Words: Noninvasive ventilation; Respiratory insufficiency; Treatment failure; Infant, premature; Infant, newborn

서론

신생아의 출생 시 호흡곤란은 후기 미숙아 및 만삭아의 이환율과 사망률에 크게 기여하고 있 으며, 신생아집중치료실에 입원하는 가장 흔한 원인 중 하나이다 ${ }^{1)}$. 재태연령 34주 미만의 미숙 아에서는 더 흔하게 발생하지만, 신생아집중치료실에 입원하는 후기 미숙아의 $29 \%$ 및 만삭아
Received: 26 December 2021

Revised: 15 February 2022

Accepted: 15 February 2022

Correspondence to: Gyu Hong Shim, $\mathrm{MD}$

Department of Pediatrics, Inje University Sanggye Paik Hospital, 1342 Dongil-ro, Nowon-gu, Seoul 01757, Korea

Tel: +82-2-950-1632

Fax: +82-2-950-1246

E-mail: peddoc@paik.ac.kr

Copyright(c) 2022 By Korean Society of Neonatology

This is an Open-Access article distributed under the terms of the Creative Commons At tribution Non-Commercial License (http:// creativecommons.org/licenses/by-nc/4.0), which permits unrestricted non-commercial use, distribution, and reproduction in any medium, provided the original work is pro perly cited. 
의 $15 \%$ 에서 치료가 필요한 호흡기계 질환이 발생한다고 알려져 있 다 ${ }^{2)}$.

과거에 신생아의 중증 호흡곤란의 치료로 기관 내 삽관 이후 침습 적인 환기를 적용하였으나, 최근 비침습적 환기의 발달 및 INSURE (INtubation-SURfactant-Extubation)법과 최소 침습 폐표면활 성제 투여법(minimally invasive surfactant therapy) 등의 발달 로 인하여 일차적인 호흡곤란의 치료에서도 비강 내 지속적 양압환 기요법(continuous positive airway pressure) 등의 비침습적 환 기를 사용하는 빈도가 점점 높아지고 있다3). 이러한 현상은 극소 미 숙아에서 두드러지게 나타나고 있고, 현재 미숙아의 호흡곤란의 일 차적인 치료로 침습적 환기와 기관 내 삽관을 통한 폐표면활성제 투 여법 대신 비강 내 지속적 양압환기요법과 같은 비침습적 환기 적용 이후 선택적인 폐표면활성제 투여법이 선호되고 있닫). 그리고, 그 연장 선상에서 후기 미숙아 및 만삭아에서도 일차적인 호흡곤란의 치료로 비침습적인 환기법이 많이 사용되고 있다5).

특히 비강 내 간헐적 양압환기요법(nasal intermittent positive pressure ventilation, NIPPV)은 비강 내 지속적 양압환기요법에 일정한 횟수의 팽창(inflation)이 추가된 비침습적 환기법으로 비 강 내 지속적 양압환기요법에 비하여 미숙아에 무호흡의 빈도를 줄여 줄 수 있는 것으로 나와 있어 현재 가장 많이 사용되는 비침 습적인 환기법 중 하나이다(). 이에 본원에서는 2015년부터 호흡 곤란이 있는 신생아의 일차적인 치료 중 하나로 NIPPV를 사용하 였는데, 호흡곤란이 있는 신생아에서 호기말양압(positive endexpiratory pressure)이 필요하다고 판단되거나, 모세혈 가스분석 결과 고탄산 혈증 $\left(\mathrm{pCO}_{2} \geq 60 \mathrm{~mm} \mathrm{Hg}\right)$ 이 있는 경우에 일차적인 호 흡 보조요법 중 하나로 사용하였다.

비강 내 지속적 양압환기요법과 마찬가지로 일정 비율의 환아에 서 NIPPV 적용이 실패하였는데, 현재까지 NIPPV 실패 요인에 대 한 후기 미숙아 및 만삭아에 대한 연구는 거의 없다. 이에 저자는 출 생 후 호흡곤란으로 생후 6시간 이내에 NIPPV를 적용받은 후기 미 숙아 및 만삭아에서 NIPPV 적용 실패의 관련 인자를 알아보고자 본 연구를 진행하였다.

\section{대상 및 방법}

\section{1. 연구 대상}

2015년 1월 1일부터 2020년 12월 31일까지 총 6년 동안 출생 후 호흡곤란으로 신생아집중치료실에 입원한 재태연령 $34^{+0}$ 주 이 상의 후기 미숙아 및 만삭아를 대상으로 하였고 이들의 의무기록 을 후항적으로 검토하였다. 출생 후 호흡곤란으로 생후 6시간 이 내에 NIPPV를 초기에 적용받은 신생아를 연구 대상군으로 선정
하였다. 선천성 기형이 있었던 환아 및 타 병원으로 전원 된 환아 는 분석에서 제외하였다. 이후 연구 대상군을 침습적인 환기를 적 용받지 않고 NIPPV를 적용받은 NIPPV 성공군과 기관 내 삽관 후 침습적인 환기를 적용받은 NIPPV 실패군으로 나누어 두 군 간의 임상적인 특성들을 비교하였다. NIPPV 성공군은 생후 6 시간 이내 에 NIPPV를 적용받았고 이후 입원 기간 동안 비침습적 환기만 적 용받은 환아군으로 정의하였고, NIPPV 실패군은 생후 6시간 이내 에 NIPPV를 적용받았으나 이후 여러 가지 이유로 침습적인 환기 를 1 회 이상 적용받은 환아군으로 정의하였다. 본 연구는 의료윤 리위원회(Institutional Review Board, IRB)의 심의를 통과하였 으며, IRB에 의하여 동의 면제가 허락되었다(Approval number: SGPAIK 2021-01-005).

\section{2. 자료 수집 방법}

호흡곤란으로 신생아집중치료실에 입원하여 생후 6시간 이내에 NIPPV를 초기에 적용받은 재태연령 $34^{+0}$ 주 이상의 후기 미숙아 및 만삭아의 산과적 특성, 신생아 시기의 임상적 특성, 입원 기간 중 발 견된 질환 및 치료 등에 대하여 조사하였다.

산과적 특성으로 산모의 나이, 분만 방식, 분만 장소, 다태아 여 부, 초산 여부, 조기 진통 여부, 체외 수정 여부, 태아 곤란증, 조기 양막 파수, 양수과소증, 임상적 융모양막염, 병리학적 융모양막염, 태반 이상, 산모의 당뇨병, 산모의 고혈압, 산모의 갑상선 질환 등에 대하여 조사하였다.

신생아의 임상적 특성으로는 재태연령, 출생체중, 성별, 1 분 및 5 분 아프가 점수, 출생 시 분만장에서의 처치, 부당 경량아(출생체중 10 백분위수 미만) 및 부당 중량아(출생체중 90 백분위수 이상) 등 에 대하여 조사하였다. 호흡곤란의 원인 질환(호흡곤란 증후군, 일 과성 빠른 호흡, 태변 흡인 증후군, 기흥, 선천성 폐렴 등)에 대하여 조사하였고, 동반 질환으로는 caffeine 사용이 필요한 무호흡, 치 료가 필요한 저혈압, 치료가 필요한 폐동맥고혈압증, 치료가 필요 한 동맥관 개존증, 신생아 패혈증, 뇌실 주위 백질연화증, 고혈당, 치료가 필요한 신생아 황달 및 사망 등에 대해 조사하였다. 혈액 검 사는 입원 초기에 처음으로 시행된 일반 혈액 검사, 생화학 검사 와 모세혈 가스분석 결과를 조사하였다. 신생아에게 시행된 치료로 는 폐표면활성제 사용 유무, 산소 사용, 고유량 비강 카뉼라(highflow nasal cannula) 사용, NIPPV 사용 및 침습적인 인공환기기 사용 등에 대하여 조사하였고, 완전 경장 영양 $(\geq 100 \mathrm{~mL} / \mathrm{kg} / \mathrm{day})$ 도달 기간, 총 정맥영양의 필요성, 항생제 사용 기간, 및 입원 기간 등에 대하여 조사하였다. NIPPV 사용에 있어서 생후 첫날 24시 간 이내에 최대의 respiratory severity score (RSS)를 구하기 위 하여 흡입산소분율(fraction of inspired oxygen)과 평균 기도압 (mean airway pressure)이 조사되었다. 


\section{3. 정의}

조기 양막 파수는 분만 18 시간 이전에 양막이 파열된 경우로 정 의하였고 ${ }^{7)}$, 병리학적 융모양막염의 경우 병리학적 검사에서 중증 도 2 이상의 양막 또는 융모 기저막염인 경우나 중증도 1 이상의 funisitis가 있을 때로 정의하였닥). 신생아 호흡곤란 증후군의 경 우에는 뚜렷한 호흡곤란 증후를 보이며 흥부방사선 사진상 폐용적 의 감소 또는 공기-기관지 음영(air-bronchogram) 등의 의심 소 견이 있어 폐표면활성제를 투여받은 경우로 하였다 ${ }^{8}$. 신생아의 일 과성 빠른 호흡은 분당 60 회 이상의 빈호흡, 그렁거림, 흡기성 함몰 등의 증상과 함께 양측성 폐포 및 간질성 부종, 폐문 주변 부위 음영 증가 및 과팽창 등의 영상의학적 소견이 보일 때로 정의하였다 ${ }^{1)}$. 태 변 흡인 증후군은 태변 착색된 양수, 분만 직후 또는 출생 초기에 발 생한 호흡곤란, 태변 흡인 증후군에 합당한 흥부방사선영상 소견으 로 양측 폐의 과팽창, 불규칙한 폐음영 감소 또는 무기폐 등이 있는 경우로 정의하였다.9). 기흥은 폐에 공기누출이 있는 환자 중에 흥강 천자 이상의 치료가 필요한 경우로 정의하였다. 신생아 폐동맥고혈 압증은 임상적으로 동맥관 전과 후의 산소포화도가 $5 \%-10 \%$ 이상 차이가 발생하며 소아심장분과전문의가 시행한 심장 초음파검사에 서 삼첨판 역류 $3.5 \mathrm{~m} / \mathrm{sec}$ 이상 혹은 우심실 최대 수축기압, 심방 수준에서의 우좌 단락의 유무, 수축기말 역설적 심실중격 운동 유무 를 평가하여 진단 ${ }^{10)}$ 받은 이후 약물 치료를 시행한 경우로 정의하였 다. 패혈증은 혈액 배양검사에서 병원균이 1쌍 이상 동정된 경우나 피부 상재균이 2 쌍 이상에서 나오고 임상 증상이 있는 경우로 정의 하였다 ${ }^{11}$. 호흡과 심박수에 대한 감시 관찰 중에 심박수가 100 회 미 만으로 떨어지는 경우를 서맥으로 정의하였고, 15 초 이상 호흡이 없거나 15초 미만이더라도 심박수가 분당 100회 미만으로 측정되 면서 산소포화도가 $85 \%$ 미만으로 떨어진 경우를 무호흡으로 간주 하였다. 뇌실 주위 백질연화증은 뇌초음파검사 또는 뇌 자기공명영 상에서 백질 주변에 낭종성 변화를 보이는 경우로 정의하였다. 고혈 당의 경우 $150 \mathrm{mg} / \mathrm{dL}$ 이상의 고혈당이 생후 첫 24시간 이내에 있 었던 경우로 정의하였다. RSS는 동맥카테터 유지가 힘든 신생아에 서 고안된 점수로 평균 기도압과 흡입산소분율을 곱해서 얻어지는 점수로 정의하였다 ${ }^{12)}$.

\section{4. 호흡 보조}

후기 미숙아 또는 만삭아 호흡곤란의 일차적인 치료로 고유량 비 강 카뉼라, NIPPV 또는 침습적인 인공환기기 등을 적용하였다. 흡 입 산소 요구량이 크지 않고, 혈액 가스검사가 안정적이며, 호기말 양압의 적용이 필요 없다고 판단되는 경우에는 고유량 비강 카뉼라 를 적용하였다. 초기 고유량 비강 카뉼라로 호흡일 증가가 의심되 거나 흡입산소분율 0.4 로 산소 포화도 유지가 어려운 경우 또는 호 기말양압의 적용이 필요하다고 판단되는 경우에는 Infant Flow ${ }^{\circledR}$
SiPAP (CareFusion, San Diego, CA, USA)을 통하여 NIPPV를 적용하였다. NIPPV의 초기 설정값으로 호흡수 분당 30-60회, 흡 기 시간 0.3-0.4초, 호기말양압은 5-6 $\mathrm{cmH}_{2} \mathrm{O}$, 그리고 최대 흡기 압은 7-10 $\mathrm{cmH}_{2} \mathrm{O}$ 로 설정하였다. 기관 내 삽관을 통한 침습적 환 기의 적용은 혈액 가스 분석에서 $\mathrm{pH}$ 가 7.25 미만이면서 이산화탄 소 분압이 $65 \mathrm{~mm} \mathrm{Hg}$ 이상인 경우 고려하였고, NIPPV 적용 시 최 소 침습 폐표면활성제 투여법 또는 INSURE법으로 폐표면활성제 를 투여하였는데도 불구하고 흡입산소분율 0.4-0.6에도 산소포화 도가 $90 \%$ 가 넘지 않은 경우 추가적으로 고려하였다.

\section{5. 통계}

통계학적인 분석을 위해 SPSS software version 25.0 for Windows (IBM Co., Armonk, NY, USA)를 사용하였으며, 범주 형 변수들은 카이제곱 검정과 피셔 검정을 사용하고 연속변수들은 Student's $t$-test과 Mann Whitney $U$-test를 사용하여 분석하였 으며, $P$ 값이 0.05 미만인 경우를 통계학적으로 의미가 있다고 판 단하였다. 그리고, NIPPV 적용의 실패와 관련된 인자를 알아보고 자 $P$ 값이 0.10 미만인 인자들을 대상으로 다중 로지스틱 회귀분석 을 진행하였다.

\section{결과}

2015년 1월 1일부터 2020년 12월 31일까지 출생 후 6시간 이 내에 호흡곤란으로 NIPPV를 적용받은 재태연령 34주 이상의 신생 아 132 명을 대상으로 연구를 진행하였다. 입원 중 다른 병원으로 전원 된 환아 2 명, 선천성 기형이 있었던 환아 3 명을 제외한 총 127 명의 신생아 중 NIPPV 성공군 82명, NIPPV 실패군 45 명을 대상 으로 하였다.

\section{1. 두 군 간의 임상적 특징의 비교}

NIPPV 성공군과 실패군 비교에서 출생 장소는 NIPPV 실패군에 서 성공군에 비하여 원외 출생이 많았으며, 폐표면활성제 투여 빈도 도 더 높았다, 두 군 간 첫날 시행한 혈액검사 결과 비교에서 NIPPV 실패군이 성공군에 비하여 총 백혈구수 $25,000 / \mathrm{\mu L}$ 이상의 빈도가 더 높았다. NIPPV 사용에 있어서 생후 24 시간 이내에 측정한 생 후 첫날 최대 흡입산소분율 0.4 이상의 빈도와 생후 첫날 최고 RSS $\geq 2.5$ 의 빈도는 NIPPV 실패군에서 성공군에 비하여 통계적으로 유의하게 더 높았다(Table 1).

\section{2. 두 군 간의 유병률 비교}

두 군의 NIPPV 사용 적응증이 된 호흡곤란의 원인은 NIPPV 
Table 1. Comparisons of Clinical Characteristics between Infants with Nasal Intermittent Positive Pressure Ventilation Success and Failure

\begin{tabular}{|c|c|c|c|}
\hline Characteristic & $\begin{array}{l}\text { NIPPV } \\
\text { success } \\
(n=82)\end{array}$ & $\begin{array}{l}\text { NIPPV } \\
\text { failure } \\
(n=45)\end{array}$ & $P$-value \\
\hline Gestational age (wk) & $36^{+4} \pm 2^{+1}$ & $37^{+2} \pm 1^{+6}$ & 0.076 \\
\hline Birth weight (g) & $2,829 \pm 674$ & $2,994 \pm 440$ & 0.100 \\
\hline Male sex & $48(58.5)$ & $30(66.7)$ & 0.368 \\
\hline Outborn & $28(34.1)$ & $32(71.1)$ & $<0.001$ \\
\hline Nulliparous & $23(28.0)$ & $17(37.8)$ & 0.259 \\
\hline Fetal distress & $3(8.9)$ & $4(3.7)$ & 0.244 \\
\hline SGA & $5(6.1)$ & $2(4.4)$ & 1.000 \\
\hline LGA & $8(9.8)$ & $4(8.9)$ & 1.000 \\
\hline Maternal age & $32.5 \pm 5.3$ & $34.1 \pm 5.2$ & 0.109 \\
\hline C-section & $54(65.9)$ & $35(77.8)$ & 0.160 \\
\hline Antenatal steroids & $10(12.2)$ & $3(6.7)$ & 0.379 \\
\hline Multiple & $6(7.3)$ & $1(2.2)$ & 0.420 \\
\hline Oligohydramnios & $2(2.4)$ & $1(2.2)$ & 1.000 \\
\hline Maternal GDM & $9(11.0)$ & $6(13.3)$ & 0.694 \\
\hline Maternal PIH & $4(4.9)$ & $5(11.1)$ & 0.278 \\
\hline PROM & $7(8.5)$ & $4(8.9)$ & 1.000 \\
\hline HCAM & $6(7.3)$ & $2(1.6)$ & 0.711 \\
\hline MSAF & $4(4.9)$ & $5(11.1)$ & 0.278 \\
\hline DR resuscitation & $15(18.3)$ & $6(13.3)$ & 0.472 \\
\hline 1-min Apgar score & $7.8 \pm 1.4$ & $8.1 \pm 1.1$ & 0.257 \\
\hline 5-min Apgar score & $8.9 \pm 1.0$ & $9.2 \pm 1.0$ & 0.136 \\
\hline Surfactant & $33(40.2)$ & $40(88.9)$ & $<0.001$ \\
\hline WBC initial $(\geq 25,000 / \mu \mathrm{L})$ & $9(11.0)$ & $15(33.3)$ & 0.002 \\
\hline pH initial $(<7.25)$ & $30(36.6)$ & $19(42.2)$ & 0.553 \\
\hline $\mathrm{pCO}_{2}$ initial ( $\geq 60 \mathrm{~mm} \mathrm{Hg}$ ) & $29(35.4)$ & $21(46.7)$ & 0.212 \\
\hline Hyperglycemia ( $\geq 150 \mathrm{~mm} / \mathrm{dL}$ ) & $11(13.4)$ & $18(40.0)$ & 0.001 \\
\hline $\mathrm{FiO}_{2} \max \geq 0.40$ & $33(40.2)$ & $40(88.9)$ & $<0.001$ \\
\hline $\mathrm{RSSmax} \geq 2.50$ & $16(19.5)$ & $34(75.6)$ & $<0.001$ \\
\hline
\end{tabular}

Values are expressed as mean \pm standard deviation or number (\%).

Abbreviations: NIPPV, nasal intermittent positive pressure ventilation; SGA, small for gestational age; LGA, large for gestational age; GDM, gestational diabetes mellitus; $\mathrm{PIH}$, pregnancy-induced hypertension; PROM, premature rupture of membrane; HCAM, histologic chorioamnionitis; MSAF, meconium staining amniotic fluid; DR, delivery room; WBC, white blood cell count; $\mathrm{FiO}_{2}$, fraction of inspired oxygen; RSS, respiratory severity score.

실패군에서는 호흡곤란 증후군이 29명(64.4\%)으로 가장 많았고, $\mathrm{NIPPV}$ 성공군에서는 신생아 일과성 빠른 호흡이 42 명(51.2\%)으 로 가장 많았다.

두 군 간 유병률 비교에서는 NIPPV 실패군에서 치료가 필요한 기흥, caffeine 사용이 필요한 무호흡, 치료가 필요한 저혈압, 치료 가 필요한 폐동맥고혈압증, 치료가 필요한 동맥관 개존증 및 치료가
Table 2. Comparison of Neonatal Morbidities between Infants with Nasal Intermittent Positive Pressure Ventilation Success and Failure

\begin{tabular}{|c|c|c|c|}
\hline Variable & $\begin{array}{l}\text { NIPPV } \\
\text { success } \\
(n=82)\end{array}$ & $\begin{array}{l}\text { NIPPV } \\
\text { failure } \\
(n=45)\end{array}$ & $P$-value \\
\hline Causes of respiratory distress & & & $<0.001$ \\
\hline RDS & $31(37.8)$ & $29(64.4)$ & 0.004 \\
\hline TTN & $42(51.2)$ & $3(6.7)$ & $<0.001$ \\
\hline MAS & $8(9.8)$ & $12(26.7)$ & 0.012 \\
\hline Others & $1(1.2)$ & $1(2.2)$ & 1.000 \\
\hline Pneumothorax & $3(3.7)$ & $7(15.6)$ & 0.033 \\
\hline Caffeine administration & $8(9.8)$ & $11(24.4)$ & 0.026 \\
\hline Hypotension & $4(4.9)$ & $24(53.3)$ & $<0.001$ \\
\hline Pulmonary hypertension & 0 & $10(22.2)$ & $<0.001$ \\
\hline PDA requiring treatment & 0 & $6(13.3)$ & 0.002 \\
\hline Culture proven sepsis & $1(1.2)$ & $1(2.2)$ & 1.000 \\
\hline PVL & $1(1.2)$ & $4(8.9)$ & 0.053 \\
\hline Jaundice requiring phototherapy & $26(31.7)$ & $31(68.9)$ & $<0.001$ \\
\hline $\begin{array}{l}\text { Duration of non-invasive ventilation } \\
\text { (d) }\end{array}$ & $5.30 \pm 1.93$ & $5.20 \pm 2.18$ & 0.788 \\
\hline $\begin{array}{l}\text { Duration of total respiratory support } \\
\text { (d) }\end{array}$ & $5.30 \pm 1.93$ & $9.47 \pm 5.06$ & $<0.001$ \\
\hline Duration of hospital stay (d) & $14.6 \pm 6.7$ & $19.9 \pm 8.4$ & $<0.001$ \\
\hline $\begin{array}{l}\text { Number of days until full enteral } \\
\text { feeding (d) }\end{array}$ & $5.00 \pm 1.52$ & $9.00 \pm 3.93$ & $<0.001$ \\
\hline Duration of TPN (d) & $3.18 \pm 2.89$ & $8.73 \pm 4.38$ & $<0.001$ \\
\hline Duration of antibiotic uses (d) & $3.21 \pm 2.01$ & $5.71 \pm 3.97$ & $<0.001$ \\
\hline Mortality & 0 & 0 & 1.000 \\
\hline
\end{tabular}

Values are expressed as number (\%) or mean \pm standard deviation.

Abbreviations: NIPPV, nasal intermittent positive pressure ventilation; RDS, respiratory distress syndrome; TTN, transient tachypnea of the newborn; MAS, meconium aspiration syndrome; PDA, patent ductus arteriosus; PVL, periventricular leukomalacia; TPN, total parenteral nutrition.

필요한 신생아 황달 등의 빈도가 더 높았다.

두 군 간 비침습적 환기의 적용 기간은 차이가 없었으나, 전체 호 흡 보조 요법 필요 기간, 입원 기간, 완전 경장 영양 도달 기간, 총 정 맥영양 투여 기간, 항생제 사용 기간 등이 NIPPV 실패군에서 더 길 었다(Table 2).

\section{3. 세부 그룹 분류}

임상적 특성 비교에서 후기 미숙아에서는 NIPPV 실패군에서 출 생체중이 상대적으로 무거웠으며, 원외 출생이 더 많았고, 폐표면 활성제 투여의 빈도가 더 높았다. 그리고, NIPPV 실패군에서 생후 첫날 흡입산소분율 0.4 이상의 빈도와 생후 첫날 최고 RSS $\geq 2.5$ 의 빈도는 성공군에 비하여 통계적으로 유의하게 더 높았다. 만삭아에 서는 NIPPV 실패군에서 초산모가 더 많았고, 폐표면활성제 투여 의 빈도가 더 높았으며, 호흡곤란 증후군의 비율이 상대적으로 높 
았다. 만삭아에서 첫날 시행한 혈액검사 결과 비교에서는 NIPPV 실패군이 성공군에 비하여 총 백혈구수 $25,000 / \mu \mathrm{L}$ 이상의 빈도가 더 높았다. 만삭아에서도 후기 미숙아에서와 같이 NIPPV 실패군에 서 생후 첫날 흡입산소분율 0.4 이상의 빈도와 생후 첫날 최고 RSS $\geq 2.5$ 의 빈도는 성공군에 비하여 통계적으로 유의하게 더 높았다 (Table 3).

후기 미숙아의 유병률 비교에서는 NIPPV 실패군에서 caffeine 사용이 필요한 무호흡, 치료가 필요한 저혈압, 치료가 필요한 신생
아 황달 등이 더 많았다. 만삭아의 유병률 비교에서는 치료가 필요 한 저혈압, 치료가 필요한 폐동맥고혈압증, 치료가 필요한 신생아 황달 등이 더 많았다. 후기 미숙아 및 만삭아에서 호흡 보조 요법 필 요 기간, 입원 기간, 완전 경장 영양 도달 기간, 총 정맥영양 투여 기 간, 항생제 사용 기간 등이 NIPPV 실패군에서 더 길었다(Table 4).

\section{NIPPV 실패의 관련 인자}

NIPPV 실패에 대한 독립적인 관련 인자를 분석하기 위하여 Table 1에 있는 변수 중 $P<0.1$ 인 요인들을 대상으로 다중 로지

Table 3. Subgroup Analysis of Clinical Characteristics between Infants with Nasal Intermittent Positive Pressure Ventilation Success and Failure

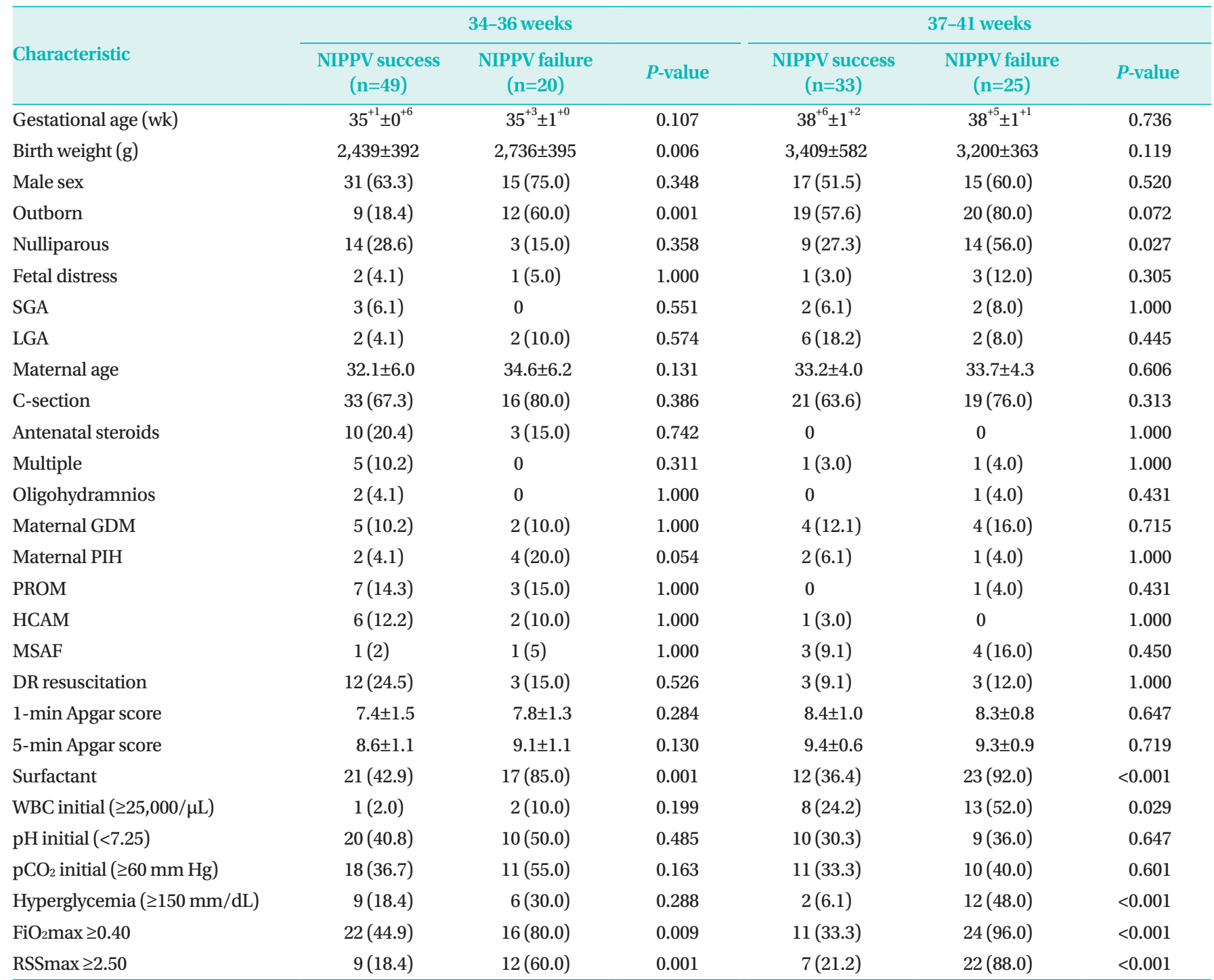

Values are expressed as mean \pm standard deviation or number (\%).

Abbreviations: NIPPV, nasal intermittent positive pressure ventilation; SGA, small for gestational age; LGA, large for gestational age; GDM, gestational diabetes mellitus; PIH, pregnancy-induced hypertension; PROM, premature rupture of membrane; HCAM, histologic chorioamnionitis; MSAF, meconium-stained amniotic fluid; DR, delivery room; WBC, white blood cell count; $\mathrm{FiO}_{2}$, fraction of inspired oxygen; RSS, respiratory severity score. 
스틱 회귀분석을 시행하였다. 원외 출생 여부(relative risk [RR], 5.50; 95\% confidence interval [CI], 1.59-19.12; $P=0.007$ ), 폐 표면활성제 투여 여부(RR, 4.61; 95\% CI, 1.09-19.42; $P=0.037)$ 및 생후 첫날 최고 RSS $\geq 2.5$ (RR, 8.43; 95\% CI, 2.23-31.87; $P=0.002)$ 가 NIPPV 실패의 독립적인 관련 인자였다. 후기 미숙아 및 만삭아에서 NIPPV 실패에 대한 독립적인 관련 인자를 분석하 기 위하여 Table 3에 있는 변수 중 $P<0.1$ 인 요인들을 대상으로 다 중 로지스틱 회귀분석을 시행하였다. 후기 미숙아는 원외 출생 여 부(RR, 8.24; 95\% CI, 1.30-52.13; $P=0.025)$ 및 생후 첫날 최고 $\mathrm{RSS} \geq 2.5$ (RR, 15.45 ; 95\% CI, 1.66-144.19; $P=0.016$ )가 독립 적인 NIPPV 실패의 관련 인자였으며, 만삭아에서는 원외 출생 여 부(RR, 4.67; 95\% CI, 1.50-14.60; $P=0.008$ ), 폐표면활성제 투여 여부(RR, 4.45; 95\% CI, 1.06-18.78; $P=0.042$ ) 및 생후 첫날 최고 $\mathrm{RSS} \geq 2.5$ (RR, 7.48; 95\% CI, 2.13-26.34; $P=0.002$ )가 독립적인 관련 인자였다(Table 5).

\section{고찰}

본 연구에서는 출생 후 호흡곤란으로 NIPPV를 적용받은 재태연 령 34 주 이상의 신생아에서 NIPPV 적용 실패의 독립적인 관련 인 자는 원외 출생, 폐표면활성제의 투여 필요 및 생후 첫날 최고 RSS $\geq 2.5$ 이었다. 재태연령에 따른 추가 분석에서 후기 미숙아는 낮은 재태연령, 원외 출생 여부 및 생후 첫날 최고 RSS $\geq 2.5$ 등이 통계 적으로 유의한 NIPPV 실패의 관련 인자였으며, 만삭아에서는 원외 출생 여부, 폐표면활성제의 투여 필요 여부 및 생후 첫날 최고 RSS $\geq 2.5$ 등이 독립적인 관련 인자였다.

신생아 호흡곤란의 치료로 고유량 비강 캐뉼라 또는 비강 내 지속 적 양압 환기 요법 등의 비침습적 환기가 일차적으로 적용되는 사례 가 늘고 있다6,13-15). 2013년 Schmolzer 등'16)은 체계적 문헌고찰을 통하여 일차적으로 비강 내 지속적 양압 환기 요법을 적용한 후 필 요 시 폐표면활성제를 투여하는 것이 기관 내 삽관 후 침습적인 환 기를 시행하는 것보다 기관지폐 형성 이상 또는 사망률을 줄일 수 있다는 것을 보여주었다. 이와 동시에 미숙아에서 비강 내 지속적

Table 4. Subgroup Analysis of Neonatal Morbidities between Infants with Nasal Intermittent Positive Pressure Ventilation Success and Failure

\begin{tabular}{|c|c|c|c|c|c|c|}
\hline \multirow[b]{2}{*}{ Variable } & \multicolumn{3}{|c|}{ 34-36 weeks } & \multicolumn{3}{|c|}{ 37-41 weeks } \\
\hline & $\begin{array}{l}\text { NIPPV success } \\
\quad(n=49)\end{array}$ & $\begin{array}{l}\text { NIPPV failure } \\
\quad(n=20)\end{array}$ & $P$-value & $\begin{array}{l}\text { NIPPV success } \\
\quad(n=33)\end{array}$ & $\begin{array}{l}\text { NIPPV failure } \\
\quad(n=25)\end{array}$ & $P$-value \\
\hline RDS & $22(44.9)$ & $14(70.0)$ & 0.058 & $9(27.3)$ & $15(60.0)$ & 0.012 \\
\hline TTN & $25(51.0)$ & $2(10.0)$ & 0.002 & $17(51.5)$ & $1(4.0)$ & $<0.001$ \\
\hline Pneumothorax & $2(4.1)$ & $4(20.0)$ & 0.054 & $1(3.0)$ & $3(12.0)$ & 0.305 \\
\hline Caffeine uses & $8(16.3)$ & $8(40.0)$ & 0.035 & 0 & $3(12.0)$ & 0.075 \\
\hline Hypotension & $3(6.1)$ & $9(45.0)$ & $<0.001$ & $1(3.0)$ & $15(60.0)$ & $<0.001$ \\
\hline Pulmonary hypertension & 0 & $2(10.0)$ & 0.081 & 0 & $8(32.0)$ & 0.001 \\
\hline Duration of non-invasive ventilation (d) & $5.24 \pm 1.80$ & $4.95 \pm 1.54$ & 0.522 & $5.48 \pm 2.14$ & $5.40 \pm 2.60$ & 0.992 \\
\hline Duration of total respiratory support (d) & $5.24 \pm 1.80$ & $8.30 \pm 3.00$ & $<0.001$ & $5.48 \pm 2.14$ & $10.40 \pm 6.14$ & 0.001 \\
\hline Duration of hospital stay (d) & $15.7 \pm 7.6$ & $19.7 \pm 6.7$ & 0.047 & $12.9 \pm 4.8$ & $20.2 \pm 9.7$ & 0.002 \\
\hline Number of days until full enteral feeding (d) & $4.90 \pm 1.34$ & $8.65 \pm 3.60$ & $<0.001$ & $5.15 \pm 1.75$ & $9.28 \pm 4.23$ & $<0.001$ \\
\hline Duration of TPN (d) & $3.06 \pm 2.71$ & $8.20 \pm 4.34$ & $<0.001$ & $3.36 \pm 3.16$ & $9.16 \pm 4.45$ & $<0.001$ \\
\hline Duration of antibiotic uses (d) & $2.94 \pm 1.09$ & $5.60 \pm 4.47$ & 0.016 & $3.61 \pm 2.86$ & $5.80 \pm 3.62$ & 0.016 \\
\hline Mortality & 0 & 0 & 1.000 & 0 & 0 & 1.000 \\
\hline
\end{tabular}

Values are expressed as mean \pm standard deviation or number $(\%)$.

Abbreviations: NIPPV, nasal intermittent positive pressure ventilation; RDS, respiratory distress syndrome; TTN, transient tachypnea of the newborn; MAS, meconium aspiration syndrome; PDA, patent ductus arteriosus; PVL, periventricular leukomalacia; TPN, total parenteral nutrition. 
Table 5. Factors Associated with Nasal Intermittent Positive Pressure Ventilation Success and Failure

\begin{tabular}{|c|c|c|c|c|c|c|}
\hline \multirow{2}{*}{ Variable } & \multicolumn{2}{|l|}{ All ages } & \multicolumn{2}{|c|}{ 34-36 weeks } & \multicolumn{2}{|c|}{$37-41$ weeks } \\
\hline & RR (95\% CI) & $P$-value & RR (95\% CI) & $P$-value & RR (95\% CI) & $P$-value \\
\hline Higher GA & $1.01(0.94-1.09)$ & 0.750 & & & & \\
\hline Higher BW & & & $1.00(1.00-1.00)$ & 0.054 & & \\
\hline LPT & $1.30(0.16-10.28)$ & 0.806 & & & & \\
\hline Outborn & $5.50(1.59-19.12)$ & 0.007 & $8.24(1.30-52.13)$ & 0.025 & $4.67(1.50-14.60)$ & 0.008 \\
\hline Nulliparous & & & & & $0.60(0.19-1.87)$ & 0.379 \\
\hline Maternal PIH & & & $16.32(0.85-311.93)$ & 0.064 & & \\
\hline Surfactant & $4.61(1.09-19.42)$ & 0.037 & $6.54(0.74-57.57)$ & 0.091 & $4.45(1.06-18.78)$ & 0.042 \\
\hline WBC initial $(\geq 25,000)$ & $1.74(0.43-7.09)$ & 0.442 & & & $1.53(0.40-5.85)$ & 0.531 \\
\hline Hyperglycemia ( $\geq 150 \mathrm{~mm} / \mathrm{dL}$ ) & $1.85(0.58-5.88)$ & 0.297 & & & $2.03(0.63-6.54)$ & 0.235 \\
\hline $\mathrm{FiO}_{2}$ max within 24 hours $\geq 0.40$ & $1.09(0.20-6.09)$ & 0.919 & $0.47(0.04-6.30)$ & 0.567 & $1.35(0.25-7.43)$ & 0.732 \\
\hline RSSmax within 24 hours $\geq 2.50$ & $8.43(2.23-31.87)$ & 0.002 & $15.45(1.66-144.19)$ & 0.016 & $7.48(2.13-26.34)$ & 0.002 \\
\hline
\end{tabular}

Abbreviations: RR, relative risk; CI, confidence interval; GA, gestational age; BW, birth weight; LPT, late preterm infants; PIH, pregnancy-induced hypertension; WBC, white blood cell count; $\mathrm{FiO}_{2}$, fraction of inspired oxygen; $\mathrm{RSS}$, respiratory severity score.

양압 환기 요법의 효과를 높이기 위한 방법들이 고안되었는데 그 중에서 NIPPV도 추가적인 팽창으로 비강 내 지속적 양압 환기 요 법보다 추가적인 도움을 줄 수 있다는 이론적인 배경으로 1980년 대 도입이 되었는데 위천공의 위험성 등으로 많이 사용되지 못하였 다 ${ }^{17)}$. 이후 여러 연구에서 NIPPV가 비강 내 지속적 양압 환기 요법 보다 부작용이 크지 않고 효과가 비슷하거나 조금 더 좋을 수 있다 는 연구결과들로 인하여 이전보다 많이 사용되기 시작하였다 ${ }^{18-22)}$. 2012년 Meneses 등23)의 체계적 문헌고찰에서 NIPPV가 비강 내 지속적 양압 환기 요법에 비하여 기관지폐 형성 이상 또는 사망률 은 비슷하지만, 침습적 환기의 적용을 줄일 수 있다고 보고하였다. 2014년 Shi 등20)은 호흡곤란 증후군의 치료로 NIPPV와 비강 내 지속적 양압 환기 요법의 비교를 위하여 미숙아와 만삭아에서 무작 위 배정 연구를 진행하였는데 NIPPV를 적용받은 신생아에서 기관 내 삽관의 필요성이 줄어들었고, 조금 더 좋은 예후를 보여 주었다 고 하였다. 최근 시행된 메타 분석에서도 호흡곤란의 일차적인 요 법으로 NIPPV와 비강 내 지속적 양압 환기 요법을 비교하였을 때 $\mathrm{NIPPV}$ 가 더 강점이 있음을 보여주었다24).

본 연구에서 원외 출생은 후기 미숙아 및 만삭아 모두에서 NIPPV 적용 실패의 독립적인 관련 인자였다. 이전 연구들에서 미 숙아의 경우에는 원외 출생의 경우 여러 질환의 유병률이 원내 출 생에 비해 상대적으로 높고 사망률도 높다는 결과를 보여 주었는데 25,26), 후기 미숙아 및 만삭아에서의 출생 위치에 따른 유병률의 비 교 연구는 거의 없다. 다만 본 연구에서 원외 출생이 NIPPV 적용 실 패의 독립적인 관련 인자로 나온 이유는 원외 출생으로 전원 전까 지 적절한 처치를 받는데 원내 출생에 비하여 상대적으로 시간이 많 이 걸리고 이로 인하여 성공적인 NIPPV를 시행 받을 수 있는 적절 한 시간대가 지나가 버리는 문제점과 상대적으로 원외 출생 환아들
이 태변 흡입 증후군의 빈도가 높고 원내 출생 환아들이 일과성 빠 른 호흡이 빈도가 높기 때문에 발생하는 현상이 아닐까 생각된다 ${ }^{27)}$. 침습적인 환기 적용 없는 폐표면활성제 투여법인 최소 침습 폐표면 활성제 투여법 및 INSURE법 등의 빈도가 높아지고 있지만 ${ }^{16,28)}$, 태 변 흡입 증후군 환아들이 일과성 빠른 호흡 환아들보다 상대적으로 높은 비율로 침습적인 기계환기 요법 적용이 필요하게 되는 것으로 판단된다.

본 연구에서 폐표면활성제의 투여 필요 여부가 전체 환아 및 만삭 아에서 NIPPV 적용 실패의 독립적인 관련 인자였다. 이번 연구 전 까지 NIPPV 적용 실패와 폐표면활성제의 투여에 관한 후기 미숙아 및 만삭아에 대한 연구는 아직 없었다. 그러나, 재태연령 24-31주 미숙아를 대상으로 Duman 등 29 의 시행한 NIPPV와 조기 폐표면 활성제의 투여에 관한 연구에서는 본 연구와는 다르게 일찍 폐표면 활성제를 투여한 환아들에서 침습적인 환기의 필요성이 줄어든다 고 하였다. NIPPV는 아니지만 비강 내 지속적 양압환기요법의 실 패에 대한 연구들에서도 조기 폐표면활성제의 투여가 비강 내 지속 적 양압환기요법 성공의 중요한 요인이라는 것을 보여 주었다 30,31 . 이렇듯 기존의 연구와 이번 연구의 결과는 서로 다른 결과를 보이는 데 이는 대상 환아들이 이번 연구에는 후기 미숙아와 만삭아를 대상 으로 했기 때문에 조기 폐표면활성제 투여 보다는 증상이 어는 정도 진행되어 산소 요구량이 많아진 후에 폐표면활성제를 투여했기 때 문에 폐표면활성제 투여가 오히려 NIPPV 적용 실패의 독립적인 관 련 인자로 나온 것이 아닌가 생각된다.

본 연구에서 생후 첫날 최고 RSS $\geq 2.5$ 가 후기 미숙아 및 만삭아 모두에서 NIPPV 적용 실패의 독립적인 관련 인자였다. 기존의 연 구에서 NIPPV 적용 실패와 흡입산소분율 또는 RSS와 관련된 연구 는 없지만, 미숙아에서 비강 내 지속적 양압환기요법의 실패 흡입 
산소분율 또는 RSS가 독립적인 요인이라는 결과를 보인 여러 연구 들이 있다30.32-35). 특히 Pillai 등 33)은 재태연령 28주 미만의 미숙아 에서 호흡 보조 시작 초기 RSS $\geq 1.28$ 이 비강 내 지속적 양압환기 요법 실패의 독립적인 예측 인자라고 하였다. 본 연구는 출생 초기 가 아닌 출생 24 시간 이내의 최고 RSS에 대해서만 조사하였고, 흡 입산소분율보다는 생후 첫날 최고 RSS $\geq 2.5$ 가 관련이 있다고 나왔 는데, 이는 NIPPV 적용에 있어서 흡입산소분율 뿐만 아니라 평균 기도압도 조절할 수 있는 부분이면서 환아의 상태를 반영하는 것이 기 때문에 RSS가 흡입산소분율 보다 더 NIPPV 적용 실패를 예측 할 수 있는 요인이 될 수 있다고 보여진다. 위의 세가지 NIPPV 적용 실패의 독립적인 관련 인자 분석에서 알 수 있듯이 외부 출생이거나 폐표면활성제를 투여받았거나 생후 첫날 최고 RSS $\geq 2.5$ 인 후기미 숙아나 만삭아의 경우에는 NIPPV 적용에 있어서 더 세심한 관찰과 주의가 필요하다고 할 수 있다.

본 연구는 여러 제한점이 있다. 후향적 설계라는 한계점과 단일 기관의 소규모 연구라는 한계가 있다. 그리고, 비침습적인 환기법 에 대한 표준화된 자료가 없는데도 불구하고 일률적으로 NIPPV를 사용하였다는 점이 있다. 마지막으로, 호흡 보조 요법의 결정 및 폐 표면활성제 투여 등에 있어서 기준이 있었으나, 어는 정도는 의료진 의 재량에 따라 결정이 달라질 가능성이 있다는 점이다. 이러한 단 점을 극복하기 위해서는 첫째로 출생 후 호흡곤란에서의 가장 적절 한 비침습적 환기법 적용에 대한 비교 연구가 필요하며, 둘째로 각 각의 치료 등에 대한 정의가 잘 이루어진 다기관에서 시행하는 대규 모 표본의 전향적인 코호트 연구가 필요하다.

결론적으로 본 연구에서는 재태연령 34 주 이상의 신생아에서 원 외 출생 및 폐표면활성제의 투여 등이 있는 경우에 NIPPV 적용 실 패의 가능성이 높다는 것을 보여 준다. 다만 본 연구는 단일기관에 서 단기간에 시행된 후향적인 연구라는 한계점이 있기 때문에 앞 으로 장기간에 걸친 다기관의 전향적인 연구를 통하여 추가적인 NIPPV 적용 실패의 요인과 이를 예방하기 위한 방법을 알아보기 위한 추가적인 연구가 필요하다.

\section{ARTICLE INFORMATION}

\section{Ethical statement}

This study was approved by the Institutional Review Board of Inje University Sanggye Paik Hospital (Approval number: SGPAIK 2021-01-005). Informed consent was waived by the board.

\section{Conflicts of interest}

No potential conflict of interest relevant to this article was reported.

\section{Author contributions}

Conception or design: G.H.S.

Acquisition, analysis, or interpretation of data: G.H.S.

Drafting the work or revising: G.H.S.

Final approval of the manuscript: G.H.S.

\section{ORCID}

Gyu Hong Shim https://orcid.org/0000-0002-0043-3186

\section{Funding}

None

\section{Acknowledgments}

None

\section{REFERENCES}

1. Reuter S, Moser C, BaackM. Respiratory distress in the newborn. Pediatr Rev 2014;35:417-28.

2. Kommawar A, Borkar R, Vagha J, Lakhkar B, Meshram R, Taksandae A. Study of respiratory distress in newborn. Int J Contemp Pediatr 2017;4:490-4.

3. Shim GH. Update of minimally invasive surfactant therapy. Korean J Pediatr 2017;60:273-81.

4. Sweet DG, Carnielli V, Greisen G, Hallman M, Ozek E, Te Pas A, et al. European consensus guidelines on the management of respiratory distress syndrome: 2019 update. Neonatology 2019;115:432-50.

5. Mahoney AD, Jain L. Respiratory disorders in moderately preterm, late preterm, and early term infants. Clin Perinatol 2013; 40:665-78.

6. DiBlasi RM. Neonatal noninvasive ventilation techniques: do we really need to intubate? Respir Care 2011;56:1273-94.

7. Practice bulletins No. 139: premature rupture of membranes. Obstet Gynecol 2013;122:918-30.

8. Sweet DG, Carnielli V, Greisen G, Hallman M, Ozek E, Plavka $\mathrm{R}$, et al. European consensus guidelines on the management of respiratory distress syndrome: 2016 update. Neonatology 2017;111:107-25.

9. Dargaville PA, Copnell B; Australian and NewZealand Neonatal Network. The epidemiology of meconium aspiration syndrome: incidence, risk factors, therapies, and outcome. Pediatrics 2006; 
117:1712-21.

10. Jain A, McNamara PJ. Persistent pulmonary hypertension of the newborn: advances in diagnosis and treatment. Semin Fetal Neonatal Med 2015;20:262-71.

11. Wynn JL. Defining neonatal sepsis. Curr Opin Pediatr 2016; 28:135-40.

12. Ballard RA, Truog WE, Cnaan A, Martin RJ, Ballard PL, Merrill $\mathrm{JD}$, et al. Inhaled nitric oxide in preterm infants undergoing mechanical ventilation. N Engl J Med 2006;355:343-53.

13. Edwards MO, Kotecha SJ, Kotecha S. Respiratory distress of the term newborn infant. Paediatr Respir Rev 2013;14:29-36.

14. Mahmoud RA, Roehr CC, Schmalisch G. Current methods of non-invasive ventilatory support for neonates. Paediatr Respir Rev 2011;12:196-205.

15. Buckmaster AG, Arnolda G, Wright IM, Foster JP, HendersonSmart DJ. Continuous positive airway pressure therapy for infants with respiratory distress in non tertiary care centers: a randomized, controlled trial. Pediatrics 2007;120:509-18.

16. Schmolzer GM, Kumar M, Pichler G, Aziz K, O'Reilly M, Cheung PY. Non-invasive versus invasive respiratory support in preterm infants at birth: systematic review and meta-analysis. BMJ 2013;347:f5980.

17. Garland JS, Nelson DB, Rice T, Neu J. Increased risk of gastrointestinal perforations in neonates mechanically ventilated with either face mask or nasal prongs. Pediatrics 1985;76:406-10.

18. Kieran EA, Walsh H, O'Donnell CP. Survey of nasal continuous positive airways pressure (NCPAP) and nasal intermittent positive pressure ventilation (NIPPV) use in Irish newborn nurseries. Arch Dis Child Fetal Neonatal Ed 2011;96:F156.

19. Owen LS, Morley CJ, Davis PG. Neonatal nasal intermittent positive pressure ventilation: a survey of practice in England. Arch Dis Child Fetal Neonatal Ed 2008;93:F148-50.

20. Shi Y, Tang S, Zhao J, Shen J. A prospective, randomized, controlled study of NIPPV versus nCPAP in preterm and term infants with respiratory distress syndrome. Pediatr Pulmonol 2014;49:673-8.

21. Mehta P, Berger J, Bucholz E, Bhandari V. Factors affecting nasal intermittent positive pressure ventilation failure and impact on bronchopulmonary dysplasia in neonates. J Perinatol 2014; 34:754-60.

22. Roberts CT, Davis PG, Owen LS. Neonatal non-invasive respiratory support: synchronised NIPPV, non-synchronised NIPPV or bi-level CPAP. What is the evidence in 2013? Neonatology 2013;104:203-9.

23. Meneses J, Bhandari V, Alves JG. Nasal intermittent positivepressure ventilation vs nasal continuous positive airway pressure for preterm infants with respiratory distress syndrome: a systematic review and meta-analysis. Arch Pediatr Adolesc Med
2012;166:372-6.

24. Ruegger CM, Owen LS, Davis PG. Nasal intermittent positive pressure ventilation for neonatal respiratory distress syndrome. Clin Perinatol 2021;48:725-44.

25. Hedstrom A, Ryman T, Otai C, Nyonyintono J, McAdams RM, Lester D, et al. Demographics, clinical characteristics and neonatal outcomes in a rural Ugandan NICU. BMC Pregnancy Childbirth 2014;14:327.

26. Chung MY, Fang PC, Chung CH, Chen CC, Hwang KP, Chen FS. Comparison of neonatal outcome for inborn and outborn very low-birthweight preterm infants. Pediatr Int 2009;51:233-6.

27. Sodawat R, Garg P, Singh C, Sharma P. Clinico-epidemiological study of respiratory distress in newborn and associated risk factors. Int J Contemp Pediatr 2018;5:1576-82.

28. Lau C, Chamberlain RS, Sun S. Less invasive surfactant administration reduces the need for mechanical ventilation in preterm infants: a meta-analysis. Glob Pediatr Health 2017;4: $2333794 X 17696683$.

29. Duman N, Tuzun F, Sever AH, Arslan MK, Iscan B, Dilek M, et al. Nasal intermittent positive pressure ventilation with or without very early surfactant therapy for the primary treatment of respiratory distress syndrome. J Matern Fetal Neonatal Med 2016;29:252-7.

30. Murki S, Kandraju H, Oleti T, Saikiran, Gaddam P. Predictors of CPAP failure: 10 years' data of multiple trials from a single center. A retrospective observational study. Indian J Pediatr 2020;87:891-6.

31. Alarcon-Olave MC, Gomez-Ochoa SA, Jerez-Torra KA, MartinezGonzalez PL, Sarmiento-Villamizar DF, Diaz-Martinez LA, et al. Early INSURE therapy reduces CPAP failure in late preterm newborns with respiratory distress syndrome: early INSURE reduces CPAP failure in late preterm newborns. Pediatria 2021; 54:4-11.

32. Koti J, Murki S, Gaddam P, Reddy A, Reddy MD. Bubble CPAP for respiratory distress syndrome in preterm infants. Indian Pediatr 2010;47:139-43.

33. Pillai MS, Sankar MJ, Mani K, Agarwal R, Paul VK, Deorari AK. Clinical prediction score for nasal CPAP failure in pre-term VLBW neonates with early onset respiratory distress. J Trop Pediatr 2011;57:274-9.

34. Hameed NN, Abdul Jaleel RK, Saugstad OD. The use of con tinuous positive airway pressure in preterm babies with respiratory distress syndrome: a report from Baghdad, Iraq. J Matern Fetal Neonatal Med 2014;27:629-32.

35. Dargaville PA, Aiyappan A, De Paoli AG, Dalton RG, Kuschel CA, Kamlin CO, et al. Continuous positive airway pressure failure in preterm infants: incidence, predictors and consequences. Neonatology 2013;104:8-14. 